\title{
Relationship between Social Media and Academic Performance in Distance Education
}

\author{
CA Pallavi Gupta ${ }^{1, *}$, Bharti Singh $^{2}$, and Tushar Marwaha ${ }^{3}$ \\ ${ }^{1}$ Faculty-Finance, Institute of Management Technology, Centre for Distance Learning, Ghaziabad, India \\ ${ }^{2}$ Faculty-Economics, Institute of Management Technology, Centre for Distance Learning, Ghaziabad, India \\ ${ }^{3}$ Faculty-HR, Institute of Management Technology, Centre for Distance Learning, Ghaziabad, India \\ *Corresponding Author: pallavigupta@imtcdl.ac.in
}

Copyright (C) 2013 Horizon Research Publishing All rights reserved.

\begin{abstract}
The scope and method of imparting distance education to the learner has evolved over a period of time. Various models of distance education have been introduced over the years; the latest introduction is the use of Web 2.0 technologies to make distance learning more analytical, flexible, interactive, and collaborative for both the teacher and the taught. This research paper has assessed the purpose of usage of social media tools, specifically Facebook, Blogs, Google groups, SkyDrive and Twitter by the students for academic purposes. Further, the relationship between usage of Facebook and academic performance of students has been tested statistically. The study reveals that majority of the students access various social media tools for information sharing and personal interaction. The academic performance of the students is independent of the use of Facebook as a social media tool for academic purpose.
\end{abstract}

Keywords Social Media, Distance Learning Modes, Facebook, E-Learning, Academic Performance, Distance Education, ICT

\section{Executive Summary}

Purpose/Objectives - The study aims to assess the respondents' psychology towards the use of technology for academic purposes and suitable tools thereof. It also aims to study the relationship (if any) that exists between the use of social networking websites for academic purposes and the academic performance of the students. This will help in determining the feasibility of using e-enabled resources (ICT's) for enhancing the quality of the educational offerings in the Indian distance learning scenario.

Design/Methodology/Approach - A questionnaire was developed and administered to collect data. It was circulated amongst 572 students who are enrolled in the PG level management courses offered by IMT-CDL through online mode, utilizing ICT tools for course delivery and management.
Findings - The survey found that a majority of respondents (73.87\%) claimed to be using social media tools and Facebook scored 3.93 (scale of 5) in terms of usage and preference. Also, academic performance and use of Facebook for academic purposes are determined to be independent of each other. Overall, there is a favourable response to e-enablement and use of social media tools for improving student-institution interaction.

Practical Implications - The study provides glimpses into the psychology of learners (primarily working professionals) enrolled in PG level management courses via distance learning. This will in turn help in structuring course and learning methodology offerings to maximize learning and improve the learning experience for the students.

Value - Study on using ICT for enhancing the learning for distance education students in India is scant. This paper should contribute toward this.

Paper Type - Research Paper

Limitations - The survey had 109 respondents, but the complete data towards analysing the relationship between academic performance and the use of Facebook was available for only 52 students.

\section{Introduction}

King et. al. (2001) have put forward a comprehensive definition of the concept of distance education after precisely defining distance learning as, "improved capabilities in knowledge and/or behaviours as a result of mediated experiences that are constrained by time and/or distance such that the learner does not share the same situation with what is being learned." They define distance education as a "formalized instructional learning where the time/geographic situation constrains learning by not affording in-person contact between student and instructor. In person education is formalized instructional learning where the time/geographic situation constrains learning by requiring synchronous person-to-person interaction. Synchronous situations provide affordances that allow 
"real-time" interaction between student and instructor. Synchronous situations are time sensitive but geographically insensitive. Examples of such situations would be teleconferencing, video teleconferencing, online chat and CUSeeME. In contrast, asynchronous situations do not provide affordances that allow for "realtime" interaction between student and instructor. Asynchronous situations are both time and geographically insensitive. Examples of these situations are correspondence courses, e-mail and web/server-based instruction." A study conducted by Sukati et.al (2010) in University of Swaziland shows that overall there are no significant differences in the performance of students in the full time programme and those in the distance education programme so the authors recommended that the distance education is equally effective and should be promoted in order to ensure an increase in access and enhance quality. In a survey done by Perris et.al (2001), it has been pointed out that "distance education deemphasizes the role of teacher, or alternatively intends to impart such a role on the student (become an independent learner) that it becomes difficult task and is evident by students constant desire for face to face interaction."

Social media tools can be used for both synchronous and asynchronous learning and in any mode, whether blended or e-learning, selected for imparting distance education. Digital age distance learners demand flexibility, convenience, interaction and customisation that can be provided by the Web 2.0 technology. Students are satisfied with anytime, anywhere web based distance learning (Carey \& Gregory, 2002) as it offers them opportunity to maintain the appropriate balance between job, learning and household duties. Home based study is considered as the most attractive feature of distance education (Law 1997). Though few students use social media for academic practice (Chen \& Bryer, 2012, Liu, 2010) majority of them are ready to adopt social media portals for the delivery of course content (Browning et. al. 2011). Trend in distance education is largely towards the use of online technology, with a greater use of social media tools, for diffusion of education in society. In the study conducted by Stansberry (1993), younger students, who have grown up surrounded by the 'vibrant impulses' of television, video, and CD games will find electronically delivered instruction more stimulating than the traditional classroom/lecture method of education.

Instructors are increasingly using blended formats to interact with the learners with the use of social media tools (Brady, et.al. 2010, Veletsianos \& Navarette, 2012). With nearly two-thirds of all faculty using social media during class session, online video is the most common tool used in class, posted outside class, or assigned for students to view (Moran et. al. 2011). So also, students are interested to use social media tools like, video sharing $(58.2 \%)$, social networking (52.8\%), web conferencing (42.6\%), blogging (40.2\%), photo sharing (36.4\%) podcasting (33.7\%), wikis $(31.3 \%)$, electronic portfolios $(28.5 \%)$, virtual world (19.4\%), tweeting (18.5\%) and social bookmarking (18.5\%) for academic purpose (Poellhuber and Anderson, 2012). Real-time learning has been made possible by such tools. Inter-group communications made possible by these tools in distance education excites young people and motivates them to learn (Mason \& Rennie, 2007), as they value virtual personal interactions. Socialising on the virtual platform helps in information sharing, collaboration and community formation and extension (Suter et. al. 2005). The more is media used effectively, especially for communication, in a distance program, the more is the level of satisfaction from that course/program (Shepherd \& Martz, 2006).

\section{Increasing Role of Social Media in Growth of Distance Education}

Innovations in media technologies have led to major improvements in imparting knowledge and skills to the learner. Taylor (1999) proposed five stages of distance education that have evolved over a period of time with the changes in social media tools.

First Generation - This is a phase of traditional correspondence education where learning is asynchronous and mediated with print media and in certain cases with educational broadcasting.

Second Generation - With the advent of multimedia, correspondence education is supplemented by multimedia tools like CDs and Tapes.

Third Generation - Distance education in this stage becomes two-way, synchronous tele-learning with the use of audio and/or video conferencing. There is interaction with the learner who is connected to the teacher at a designated centre at a specified time, through online lectures.

Fourth Generation - This phase has flexible asynchronous online learning through internet and World Wide Web combined with online interactive multimedia. Interaction between the teacher and the learner and between the learners is possible due to internet and online learning. Learner can connect from anywhere at any time and participate in group activities. Synchronous teleconferencing is popular method in imparting education in this stage.

Fifth Generation - Intelligent flexible learning is possible in this stage, with high degree of automation with student control to asynchronous online learning and interactive multimedia. The learner has flexibility to connect through social media software, virtual world and multimedia tools like YouTube that is possible due to social media or web 2.0 tools.

The Report of the Committee to Suggest Measures to Regulate the Standards of Education being imparted through Distance Learning Mode has highlighted the various possible social media communication technologies which can enhance the reach and quality of distance learning (Table 1). 
Table 1. Social Media Communication Technologies

\begin{tabular}{|c|c|}
\hline Communication Technology & Activities \\
\hline Radio & $\begin{array}{l}\text {-Broadcast of audio programmes } \\
\text {-Counselling (informing, advising, counselling) } \\
\text {-Live interaction with learners }\end{array}$ \\
\hline Television & $\begin{array}{l}\text {-Broadcasting of video } \\
\text {-Counselling (informing, advising, counselling) } \\
\text {-Live interaction with learners through } \\
\text { teleconferencing } \\
\text {-Training of functionaries }\end{array}$ \\
\hline Telephone & -Counselling (informing, advising) and mentoring \\
\hline Computer & $\begin{array}{l}\text {-Development and maintenance of databases } \\
\text {-On-line interaction } \\
\text {-Connectivity of all centers }\end{array}$ \\
\hline Internet and Satellite & $\begin{array}{l}\text {-Institutional information } \\
\text {-Academic resources } \\
\text {-Providing academic and administrative services } \\
\text {-Videoconferencing }\end{array}$ \\
\hline Mobile & $\begin{array}{l}\text {-Institutional information } \\
\text {-Academic resources } \\
\text {-Providing academic and administrative services }\end{array}$ \\
\hline
\end{tabular}

Source: N. R. Madhava Menon, Report of the Committee to Suggest Measures to Regulate the Standards of Education being imparted through Distance Learning Mode (2011)

Though the use of social media communication technologies is highly emphasized in disseminating distance education and bridging the geographical gap, but these technologies will be useful only when the users are aware of the facilities offered by distance learning institutes. In a study conducted by S. Raja Rao in Dr. B. R. Ambedkar University in the year 2004, it was found that lack of information about different media lessons is the major reason for not listening media lectures or using the extended support facilities offered by the distance learning institutes. In response to the question that whether they are aware about media support offered by the University 266 (77.6\%) had stated that they are aware of it and rest of the respondents 77 (24.4\%) were not aware of media support.

With the increasing usage of social networking tools, elearning mode, which is web based teaching, is becoming more popular to impart distance education. It comprises of both static and interactive methods to impart education. Audio and video aids, hyperlinked Web pages, and live Web broadcasts are some of the static tools used for distance learning. Bulletin boards, chat rooms, instant messaging, video conferencing and discussion threads are used for providing interactive education. Figure 1 presents a comparison of the traditional distance learning mode and e-learning mode in context of programme delivery, student -faculty interaction and student organisation interaction.

\section{Research Objective}

The objective of the study is:

(1) To assess the purpose of usage of social media tools viz. Facebook, Blog, Groups, SkyDrive and Twitter by the students for academic purpose.

(2) To study the relationship between the usage of Facebook and academic performance, precisely the end-semester scores of the distance learning students

\section{Research Methodology}

Research is based on the survey conducted with Institute of Management Technology-Centre for Distance Learning students. Questionnaire was divided into four sections, Section A of the questionnaire deals with general usage patterns related to Social Networking Sites (SNS's) and the respondents' requirements. Section B deals with the usage and awareness levels of the respondents while in Section C, a tool-wise survey has been attempted. Section D captures demographic data.

The questionnaire was administered via Google Docs and sent/shared via email and Google Groups to 6 batches (2 each in the January 2011, July 2011 and January 2012 cycles) of the online mode courses of IMT-CDL. 


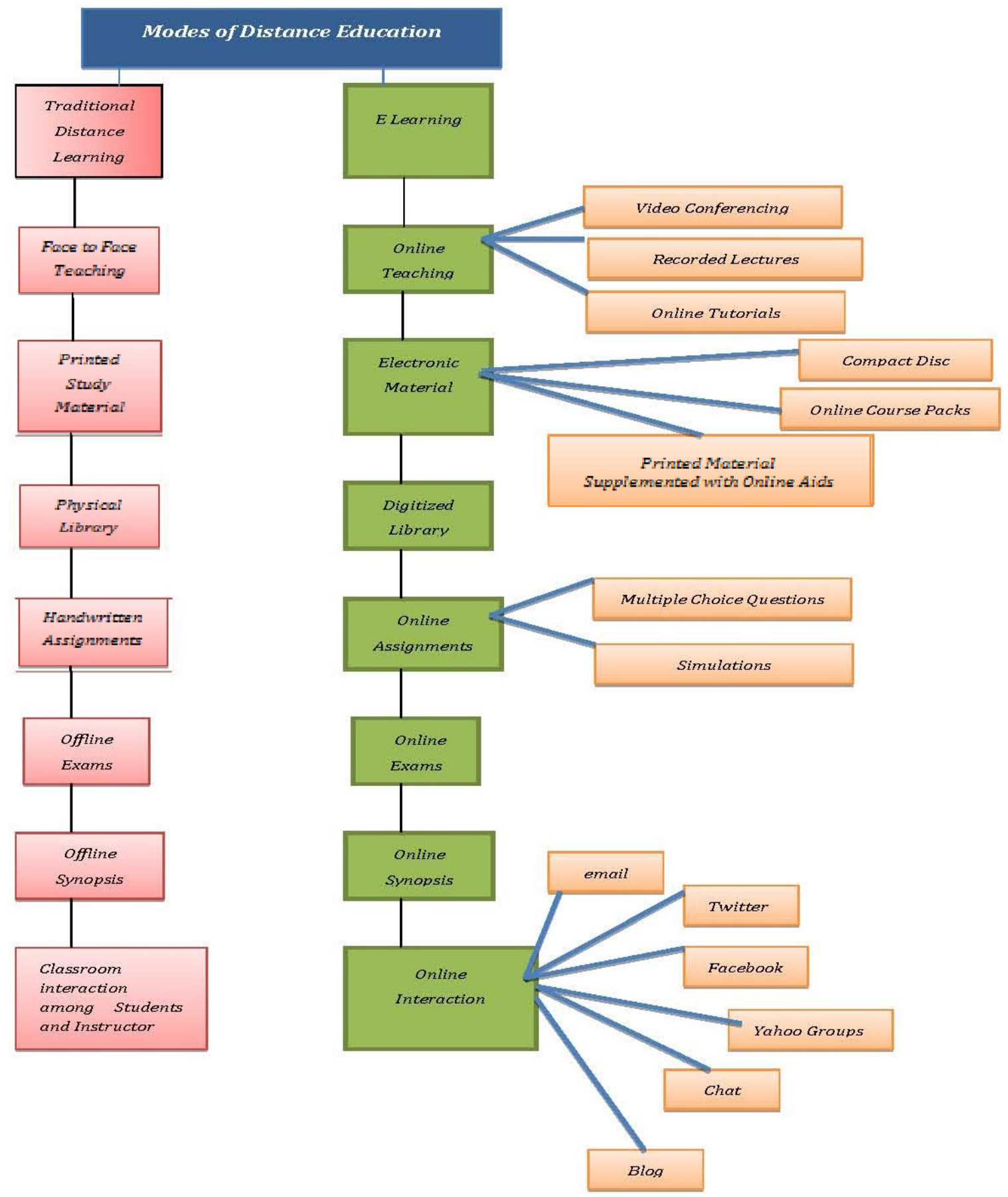

Figure 1. Flowchart of Distance Learning

The questionnaire was emailed to 572 students. Out of the 572 recipients, 1 email bounced and 2 were unable to submit the questionnaire. A total of 109 complete and usable responses were logged at a response rate of 19.1 percent (109/572). Figures 2 and Figure 3 depict the profile of the respondents.

The chi square $\left(\chi^{2}\right)$ test for independence of variables has been applied at $5 \%$ significance level to study the relationship of usage of Facebook and academic performance.
The hypothesis test for independence is:

$\mathrm{H}_{0}$ : Academic performance and use of Facebook for academic purpose are independent of each other.

$\mathrm{H}_{1}$ : Academic performance and use of Facebook for academic purposes are dependent on each other.

$$
\chi^{2}=\sum_{\text {allcells }} \frac{\left(f_{0}-f_{e}\right)^{2}}{f_{e}}
$$

Where $f_{0}$ is observed frequency and $f_{e}$ is expected 
frequency.

$$
f_{e}=\frac{\text { rowtotal }^{*} \text { columntotal }}{\text { totalsamplesize }}
$$

Degrees of freedom in a $\chi^{2}$ test of independence equals to (number of rows-1)*(number of columns-1)

\section{Data Analysis}

From the responses received $56 \%$ of the respondents use social media tools for academic purposes. Out of the total users of social media, $11 \%$ of the students use the social media for networking among themselves. The different academic purposes for which social media is used is depicted by figure 2 .

During the survey it was found that Facebook has maximum number of users so an effort has been made to study the relationship of usage of Facebook and academic performance of the students, precisely the end-semester scores of the distance learning students. The following data has been obtained after survey (figure 3 )

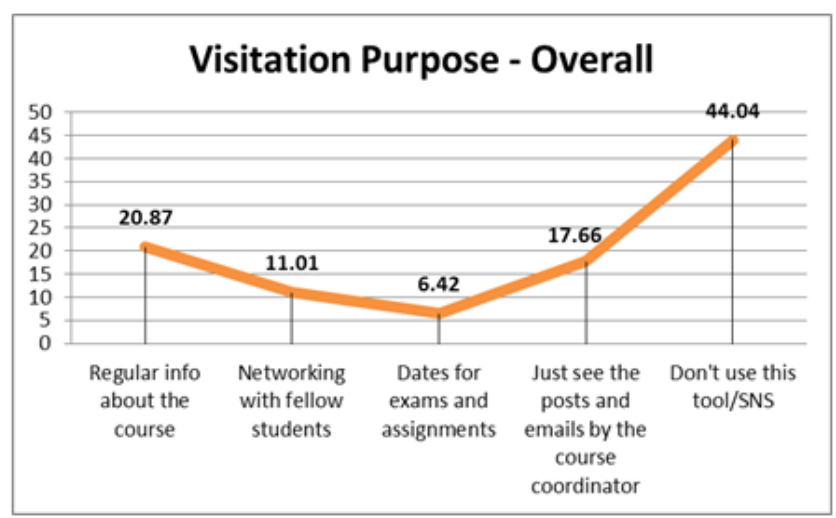

Figure 2. Overall Purpose of Site Visit

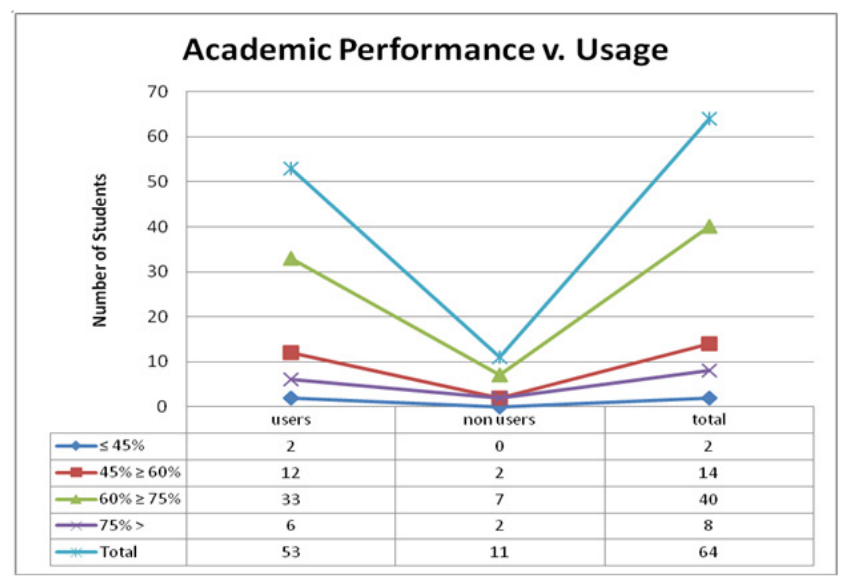

Figure 3. Academic Performance vs Usage

Chi Square test of independence is applied here to check the dependency of academic performance on the usage of Facebook.
$\mathrm{H}_{0}$ : Academic performance and use of Facebook for academic purposes are independent of each other.

$\mathrm{H}_{1}$ : Academic performance and use of social media tool Facebook for academic purposes are dependent on each other.

Table 2. Chi Square test

\begin{tabular}{|c|c|c|c|}
\hline Cell & $f_{0}$ & $f_{e}$ & $\frac{\left(f_{0}-f_{e}\right)^{2}}{f_{e}}$ \\
\hline$(1,1)$ & 2 & 1.656 & 0.0713 \\
\hline$(1,2)$ & 0 & 0.344 & 0.344 \\
\hline$(2,1)$ & 12 & 11.594 & 0.0142 \\
\hline$(2,2)$ & 2 & 2.406 & 0.0686 \\
\hline$(3,1)$ & 33 & 33.125 & 0.0005 \\
\hline$(3,2)$ & 7 & 6.875 & 0.0023 \\
\hline$(4,1)$ & 6 & 6.625 & 0.0590 \\
\hline$(4,2)$ & 2 & 1.375 & 0.2840 \\
\hline & & $\sum$ & $\mathbf{0 . 8 4 3 9}$ \\
\hline & & & \\
\hline
\end{tabular}

For a 5\% level of significance the rule for acceptance or rejection of the null hypothesis as follows:

If $\chi^{2}$ cal $>\chi_{\text {critical }}^{2}$, reject the null hypothesis, otherwise do not reject the null hypothesis.

Degrees of freedom in a $\chi 2$ test of independence equals to (number of rows- 1$) *($ number of columns- 1$)=(4-1) *(2-1)$ $=3 * 1$

$=3$

The critical $\chi^{2}$ value is $\chi^{2} 0.005,3=7.815$

The calculated $\chi^{2}$ value is $=0.8439$

So here $\chi^{2}$ cal is less than the $\chi^{2}$ critical so the null hypothesis is accepted.

Null hypothesis is accepted. Academic performance and use of Facebook for academic purposes are independent of each other.

\section{Discussion and Conclusion}

From the present study it can be inferred that the use of Facebook for academic purposes does not play any significant role in academic performance. Similarly, a study conducted by Moran et. al. (2011) shows that a large percentage of faculty members $(53 \%)$ did not consider Facebook as suitable social media tool for classroom teaching rather they regarded it to have "negative" value for use in class. A study conducted by Duvall and Schwartz (2000) "shows that no significant differences in overall academic performance between technology-adept students 
and those without technological skills". This means that there is a need to conduct further research to judge which are the most appropriate social media tools for instruction through e-learning.

With a tremendous increase in the number of internet users, per 100 people around the world from 10.6 to 30.2 from 2002 to 2010 that is around $185 \%$ (worldbank.org) there is a large opportunity to use web 2.0 technologies that can mediate distance learning and make it more analytical, flexible, interactive, and collaborative for both the teacher and the taught. If social media tools are used effectively for communication and collaboration for academic purposes it will eliminate the drawback of learning in isolation in an e-learning mode.

\section{REFERENCES}

[1] Brady, K. Holcomb, L. \& Smith, B. (2010). The use of alternative social networking sites in higher education settings: A case study of e-learning benefits of Ning in education, Journal of Interactive Online Learning, 9(2), 151-170.

[2] Browning L., Gerlich, R., \& Westermann, L., (2011) The new HD classroom: A 'Hyper Diverse' approach to engaging with students. Journal of Instructional Pedagogies. 1-10. Retrieved from http://www.aabri.com/manuscripts/10701.pdf

[3] Cary, J.O. \& Gregory, V.L. (2002), Students perception of academic motivation, interactive participation and selected pedagogical and structural factors in web based distance learning. The Journal of Education for Library and Information Science, 43(1), 6-15.

[4] Chen, B. \& Bryer, T. (2012), Investigating instructional strategies for using social media in formal and informal training. The International Review of Research in Open and Distance learning, 13(1), 87-100.

[5] Duvall,C.K.,Schwartz,R.G.,(2000). Distance Education: Relationship Between Academic Performance and Technology-Adept Adult Student.Education and Information Technologies, September 2000, Volume 5, Issue 3,pp 177-187.

[6] King, F.B., Young, M.F., Drivere-Richmond, K. \& Schrader, P.G. (2001). Defining Distance Learning and Distance Education. AACE Journal, 9(1), 1-14. Retrieved from http://www.editlib.org/p/17786.

[7] Law, S. (1997) Learning lessons: Why choose distance learning in education management?, International Journal of Education Management, 11(1), 14-25.

[8] Liu, Y. (2010), Social Media tools as a Learning Resource,
Journal of Educational Technology Development and Exchange, 3(1), 101-114

[9] Mason, R. \& Rennie, F. (2007) Using web 2.0 for Learning in the Community, Internet and Higher Eduction,10, 196-203.

[10] Menon, N.R.M. (2011). Report of the Committee to Suggest Measures to Regulate the Standards of Education Being Imparted through Distance Mode. [report] New Delhi: Ministry of Human Resource Development, Government of India

[11] Moran, M., Seaman, J. \& Hester, T. (2011) Teaching, Learning and Sharing: How Today's Higher Education Faculty use Social Media. Pearson learning Solutions and BabsonSurvey Research Group

[12] Perris, K., Zhang, W. \& Poon, T. (2001) An Investigation of Distance Learners Prefrences for and Barriers to Online Learning in Hong Kong, Indian Journal of Open Learning, 13(2), 139-149.

[13] Poellhuber, B. \& Anderson, T. (2012). Distance Students' for social media and collaboration. The International Review of Research in Open and Distance Learning, 12(6), 102-125.

[14] Raja Rao, S. (2008) AcUSe of Media Support Services: Strategies to make them popular with the Learners, India Journal of Open Learning, 17(2), 163-173.

[15] Shepherd, M. M. \& W. M. B. Martz, (2006) Media Richness Theory and the Distance Education Environment, The Journal of Computer Information Systems, Fall 2006, 47(1).114-122.

[16] Stansberry, D. (1993, February). Taking the Plunge. NewMedia, 30-36.

[17] Sukati, C. W. S., M Magagula, C., Chandraiah, E., Simelane H. S. \&. Sithole, M. M. (2010) Conventional versus Distance Education Revisited: Does Mode Matter? India Journal of Open Learning, 3-22.

[18] Suter, V., Alexander, B. \& Kaplan, P. Social software and the Future of Conferences right now. EDUCAUSE Review, Jan-Feb., 2005, 47-59.

[19] Taylor, J. C. (1999). Distance education: The fifth generation. Proceedings of the 19th ICDE World Conference on Open Learning and Distance education, Vienna, Austria. Retrieved from http://www.tonybates.ca/2008/07/07/what-is-distance-educat ion/

[20] The World Bank (n.d.). Internet users (per 100 people). Retrieved October 3, 2012 from http://data.worldbank.org/indicator/IT.NET.USER.P2/countr ies/1W?display=graph

[21] Veletsianos, G. \& Navarette, C. (2012). Online social networks as formal learning environments: learner experiences and activities. The International Review of Research in Open and Distance Learning, 13(1), 144-166. 